\title{
Knowing the enemy: ant behavior and control in a pediatric hospital of Buenos Aires
}

\author{
Roxana Josens", Francisco J Sola, Nahuel Marchisio, María Agostina Di Renzo and Alina Giacometti
}

\begin{abstract}
Ant control is difficult in systems even where a variety of control strategies and compounds are allowed; in sensitive places such as hospitals, where there are often restrictions on the methods and toxicants to be applied, the challenge is even greater. Here we report the methods and results of how we faced this challenge of controlling ants in a pediatric hospital using baits. Our strategy was based on identifying the species present and analyzing their behavior. On the one hand, we evaluated outdoors in the green areas of the hospital, the relative abundance of ant genera, their food preferences and the behavioral dominances. On the other hand, control treatments were performed using separately two boron compounds added to sucrose solution which was not highly concentrated to avoid constrains due to the viscosity.

Most of the species in the food preference test accepted sugary food; only one species was recorded to visit it less than the protein foods. This result was consistent with the efficacy of control treatments by sugary baits within the rooms. For species that showed good acceptance of sugar solutions in the preference test outdoors, sugar bait control indoors was 100\% effective. Conversely, for the only species that foraged significantly less on sugar food, the bait treatment was ineffective. This work reveals the importance of considering the behavior and feeding preferences of the species to be controlled by toxic baits.
\end{abstract}

Keywords: Ant; Chemical control; Baits; Food preferences; Nylanderia fulva

\section{Introduction}

Many ant species are serious pests in urban environments. They may cause damage to structures, electronic devices and affect household residents; in addition, many species can sting and/or bite. Presently there is greater awareness of the risks involved in the indiscriminate release of toxicants on the environments we live and work, thus the demand for environmentally friendly control methods is growing. For ant control in urban settings, insecticides have been commonly used as perimeter barrier treatments (Mallis 1969; Ebeling 1978; Hedges 2010; Klotz et al. 2010). However, fast-acting barriers or sprays may result in ants trapped within the building in treatment (Klotz et al. 2008, 2010) or in colony budding (Hedges 2010; Buczkowski et al. 2005; Oi 2008), even increasing the foraging activity indoors (Oi et al. 1996). The use of toxic baits is, undoubtedly, the least polluting way to control these insects and it

\footnotetext{
*Correspondence: roxy@bg.fcen.uba.ar

Grupo de Estudio de Insectos Sociales, IFIBYNE-CONICET, DBBE-Facultad de Ciencias Exactas y Naturales, Universidad de Buenos Aires Pabellón II, Ciudad Universitaria (C1428EHA), Buenos Aires, Argentina
}

is easy to be commercialized and applied both in homes and buildings. Exterior application of a delayed-action toxicant could result in successful control for indoor ant infestations (Oi et al. 1996).

Ants, as insects in general, have on their cuticle different microorganisms (Beatson 1972; Bueno and CamposFarinha 1999; Santos et al. 2009), therefore they are frequently believed to be involved in food contamination and mechanical vectoring of disease agents (Beatson 1972; Fowler et al. 1993; Olaya-Masmela et al. 2005; Moreira et al. 2005). In addition, as there are minute species, they can enter places where other, larger insects, cannot (such as cockroaches, flies, mosquitoes, etc.). Moreover, ants travel long distances searching for food, circulating in these trails from several to hundreds of individuals. These characteristics give them the potential capacity to spread pathogens in sensitive places that should be kept aseptic (such as surgical environments, sites for storing sterile instruments or equipment, etc.) and move from hospital areas that may harbor pathogens to patients and between them (Beatson 1972). 
Hospitals require careful attention; neonates, infants, elderly or immunosuppressed patients are more sensitive to insect stings and to different pathogens that insects could transport, but also to the pesticides used for their control. Pesticides in sprays, liquids or powders could represent a risk to these patients (Owens 2003). For these reasons, food baits containing a toxicant are recommended to control ants and cockroaches in these sensitive places (Owens 2003; Pampiglione and Velo 2010). This method has many advantages over others: on the one hand, it avoids toxic volatiles and reduces human toxicant exposure, and localization or access to the nest is not necessary as the ants distribute the bait amongst themselves. As social insects, ants live in a colony which presents division of labor among members. The reproductive caste rarely leaves the nest, but a proportion of the sterile workers do in order to forage on different resources. Hence, foragers themselves transport the bait towards the nest, where it is distributed among the remaining colony members. For these insects, the toxicant should have a delayed action, giving them enough time to allow foraging, transport to the nest, sharing therein and recruitment.

There are commercial toxic baits with different toxicants for most urban ants. They are commercialized in different countries as gels or similar vehicles contained in syringes. However, their success is variable (O'Brien and Hooper-Bui 2005; McDonald 2012). This could be due to many reasons that affect the behavior and decision making of the ant individuals during foraging. Foragers modulate their behavior according to the colony needs (Howard and Tschinkel 1980; Josens and Roces 2000; Falibene et al. 2009), the bait properties (Josens et al. 1998; Cassill and Tschinkel 1999; Medan and Josens 2005), the toxicant and its concentration (Hooper-Bui and Rust 2001; O'Brien and Hooper-Bui 2005; Sola et al. 2013), among many other factors. It is known that nectar ingesting ants do not always reach their full crop load and usually leave the food source with partial loads (Josens et al. 1998; Dornhaus et al. 2006). Highly viscous solutions are ingested at a very low rate (Josens et al. 1998; Medan and Josens 2005; O'Brien and Hooper-Bui 2005); ants drink longer and reach smaller loads than for more dilute or less viscous solutions (Josens et al. 1998). Besides, foragers can accept or reject certain baits, recruit other ants or not and intake faster or slower from a certain fluid depending on their motivation to feed (Howard and Tschinkel 1980; Josens and Roces 2000; Falibene et al. 2009; Falibene and Josens 2008; Mailleux et al. 2006). Moreover, behavioral responses to a certain toxic bait are not always the same among different species. For two species with similar feeding habits, like the carpenter ant Camponotus mus and the Argentine ant Linepithema humile
(Newell and Barber 1913; Markin 1970; Hansen and Klotz 2005), boric acid can affect acceptance negatively for the former but not for the latter. On the other hand, borax may cause the inverse situation (Sola et al. 2013). Therefore, all these factors should be considered when developing baits for ant control.

Traditionally, the toxicological effects of pesticides were studied in cases of acute poisoning by accidental exposure to high doses of insecticide, which are well documented (Shannon et al. 2007). However, nowadays there is greater awareness of the risk of long term effects attributable to frequent exposure to doses of low concentrate pesticides (Kapoor et al. 2011; Herin et al. 2011). Also, new studies revealed the close relationship between the chronic health effects that become apparent at a given moment in life and the prolonged or repeated exposure to low doses of pesticides at earlier ages (Winans et al. 2011; Bailey et al. 2011). In this regard, pediatric hospitals should consider that their patients are particularly sensitive to pesticides, as they might have an impact on the development of a child and also contribute to the onset of diseases later (Winans et al. 2011). For example, several reports suggest an increase in the incidence of acute lymphoblastic leukemia in children by exposure to pesticides (Leiss and Savitz 1995; Infante-Rivard et al. 1999; Alexander et al. 2001; Thompson et al. 2001; Ma et al. 2002; Menegaux et al. 2006; Pombo-de-Oliveira and Koifman 2006; Rudant et al. 2007). Recently, a study conducted in Australia showed a correlation between the application of pest control treatments in homes and the posterior incidence of the mentioned pathology and also revealed a critical age period for children (2 to 3 years old) (Bailey et al. 2011). The authors argue that this window of greater sensitivity could be related to a greater exposure due to the habits and typical behavior of that age.

Taking all this into account, the pediatric hospital "Hospital de Niños Ricardo Gutiérrez" from Buenos Aires City has generally been trying to avoid the use of pesticide sprays or powders and has only been using commercial baits. Consequently, it has been facing some difficulties to control ant populations within the grounds of the hospital. Owing to this, we were summoned in September 2011. Thus, our challenge was to develop a protocol to control ants in the hospital that would improve the standards with commercial baits. In order to achieve that, we performed two different phases: 1) evaluation of the species present and some aspects of their behavior, and 2) control using baits.

\section{Material and methods The place}

The public pediatric hospital in this study occupies 3 hectares in the City of Buenos Aires (34 $35^{\prime} 39.20^{\prime \prime} \mathrm{S}$; 
$\left.58^{\circ} 24^{\prime} 40.76^{\prime \prime} \mathrm{W}\right)$. At the site, there are around 18, 1 and 2 storey buildings interspersed with green spaces with different types of vegetation: trees, grass and ornamental plants. This hospital moved to these grounds in 1896. Several of the present buildings were constructed at that time. The hospital has 300 beds and approximately 2500 medical doctors and nurses work therein; thousands of people circulate there per day.

\section{Evaluation phase}

The objectives of this phase were to evaluate which species were present in green spaces, quantify their abundance, assess their food preferences and determine which were behaviorally dominant.

The individuals collected from manual sampling, pitfall traps and food baits outdoors and also those found indoors were used to make a list of species present in there. The genus abundance was quantified from pitfall traps, and behavioral dominance and food preferences were estimated by means of food baits. Samplings were performed from December 2011 to January 2012, which corresponds to late spring and summer in our latitude.

\section{Manual sampling}

Six trained students toured the grounds sampling ants in the vegetation, grass, walls, pedestrian paths, and indoors, in order to identify the species and document which of those were associated with buildings. Samples were preserved in ethanol (96\%) in bottles labeled with the capture site and date. Manual samplings were performed on two different days between $10 \mathrm{am}$ and $3 \mathrm{pm}$. The only objective of this sampling was to contribute to the list of species present in the hospital.

\section{Pitfall trapping}

24 non-baited pitfall traps were placed twice (two weeks apart) in different green spaces of the hospital and left for two days. Each trap consisted of a $200 \mathrm{ml}$ plastic cup buried in the ground and half-filled with alcohol (70\%). Pitfalls were left for $48 \mathrm{~h}$, which allowed sampling ants with low activity at the times we did not have access to the hospital. Trapped ants were identified to species or genera with available keys (Kusnezov 1951, 1978; MacKay and MacKay 2002; Fernández 2003; Wilson 2003). Relative abundance per genus was measured as the number of ants per genus over the total number of ants collected during the study.

\section{Baiting}

Food sources were used in order to study the first genus in discovering the resource, the recruitment dynamics and the behavioral dominance among the different genera (Fellers 1987; Savolainen and Vepsäläinen 1988; Andersen 1997; Morrison et al. 2000). Four different types of food were offered simultaneously on "a station" (a square plastic sheet of $20 \mathrm{~cm} \times 20 \mathrm{~cm}$ ): commercial canned tuna in oil, commercial canned corned meat, honey-water and raw lean beef in similar amounts (ca. $1 \mathrm{~g})$. Within the square sheet, each food was placed in the center of each quarter (i.e. $10 \times 10 \mathrm{~cm}$ ). A total of 32 baits were placed on 8 stations during $70 \mathrm{~min}$. Every $10 \mathrm{~min}$ (from $\mathbf{T 0}=$ time $0 \mathrm{~min}$ to $\mathbf{T} 7=$ time $70 \mathrm{~min}$ ), a photo of each bait was taken (Canon EOS 400D XTi, Canon EF50mm Compact macro lens); recordings and notes about the species visiting the baits were also made in parallel. Later in laboratory, the number of ants per species was counted per bait from the photos taken, in conjunction with ant samples taken from food bait stations.

Offering 4 alternative types of food per station also allowed us to evaluate food preferences for the species that visited these stations. The distribution of the different species that visited the 4 food baits was compared by means of Chi Squared Homogeneity test. Then, for each species, the number of ants foraging on each food bait was compared by means of Chi Squared Goodness of Fit Test in order to establish the preferences of each species.

\section{Control phase \\ The toxic baits}

The bait consisted of sucrose solution $(20 \% \mathrm{w} / \mathrm{w})$ added with a toxicant offered in plastic tubes $(5 \mathrm{ml}$ and $10 \mathrm{~mm}$ diameter) with a plug of non-compacted cotton. It is important that the plug of cotton is set lightly so as not to dry on the outside, but does not drip when tilted down. This solution has low viscosity which is preferred for urban ant baits, because it does not present a mechanical difficulty for small species to ingest (Baker et al. 1985, Josens et al. 1998; Silverman and Roulston 2001; O'Brien and Hooper-Bui 2005; Medan and Josens 2005). The toxics used were two boron compounds: boric acid and borax (sodium borate). These boron toxicants are two of the few allowed by the toxicological service of the hospital, due to their very low toxicity for mammals.

A low concentration of the toxicant $(2 \% \mathrm{w} / \mathrm{v})$ was used to avoid ant rejection, as observed for different species (Klotz et al. 2000; Klotz 2004).

Whenever possible, two baits were offered together: one containing boric acid (BA) and the other, borax (B). This decision was based on previous data on two species which presented the opposite rejection response toward those toxicants (Sola et al. 2013). As the response of the species to be found could not be predicted, offering two alternatives of boron compounds would increase the probability that one of them would be taken to the nest. If a given species rejected a particular boron compound, it would find and feed on the other. 
Due to the constant presence of children, tubes had to be located in hidden or hard to reach places so as not to call their attention. Respecting this premise, tubes were placed as close to the ant trails as possible and fixed to the walls with tape (masking tape or duct tape) of a similar color to the background.

The control phase was performed at two scales: an extensive outer baiting for highly infested pavilions, and a focal, interior or exterior baiting for particular rooms where staff reported the presence of ants. For the former, sets of two tubes which were $10 \pm 5 \mathrm{~cm}$ close to each other were placed on the outer walls, (one tube with $B$ and the other with BA Figure 1). The content of the tubes was refilled three times per week when needed, and completely replaced once a week. On those days, ants were sampled to identify the species present in each tube. For the latter, depending on the room and the situation of the child therein, we placed a set of 2 tubes (one with $\mathrm{B}$ and the other with $\mathrm{BA}$ ) or only one tube (with $\mathrm{B}$ or $\mathrm{BA}$ depending on the species present). Tubes were also controlled three times a week in some rooms and refilled when needed. However, the treatment proved to be effective even in places without performing those refilling tasks, which demanded many man-hours, but placing several tubes at the same time.

\section{Highly infested pavilions and Focal infested rooms}

Since the beginning of the cooperation with the hospital, its director instructed both the staff and the pest control personnel to notify us if ants were detected in the interior of the buildings.

Our first step in this control phase was to identify the pavilions highly infested with ants. For that, two kinds of recordings were considered: the detection of high ant activity on outer walls and the reports of the hospital staff from the rooms. The ant activity on outer walls was evaluated by means of an outside building visual survey for detection of ant trails by a group of 6 trained students who toured the site.

\section{Results}

\section{Evaluation phase}

Considering all the sampling methods together, 15 species belonging to 12 genera were found (Table 1). Even though 14 species were detected in green areas, most were not associated to building walls. The less common species in the green areas were found only in one sector and in a very low density. The most problematic species was Nylanderia fulva; it was abundant in green areas and very frequently associated to buildings and also indoors.

\section{Relative abundance of genera}

A total of 4,767 ants were collected in the 24 pitfall traps placed in the green areas of the hospital. Their genera and, when possible, the species were determined for each individual.

The most abundant genus was the Pheidole (three species) with a $52 \%$ of the total abundance, in second place Nylanderia (one species) with $34 \%$, followed by Solenopsis (one species) with $10 \%$. The rest of the genera represented less than 5\%: Brachymyrmex, Acromyrmex, Gnamptogenys and Strumigenys (Figure 2).

A more detailed observation of each sampling site revealed that Pheidole and Nylanderia were found together in each and every site (data not shown). That means they coexisted in all the green places and seemed not to be partitioned across the premises.

\section{Behavioral dominance}

Six ant species visited the stations which offered 4 different food baits each. Table 2 shows the first genera to arrive at each station (at time T0 or T1) and the relative abundance per station at the end of our records (at time T7).

Regarding the temporal dynamics of the species visiting the baits (Figure 3), Pheidole sp2 (cf. P. radoszkowskii) was the first to arrive at all the stations. Every station was visited by the 3 species of Pheidole immediately after they were placed (time 0 or time 1 ). This

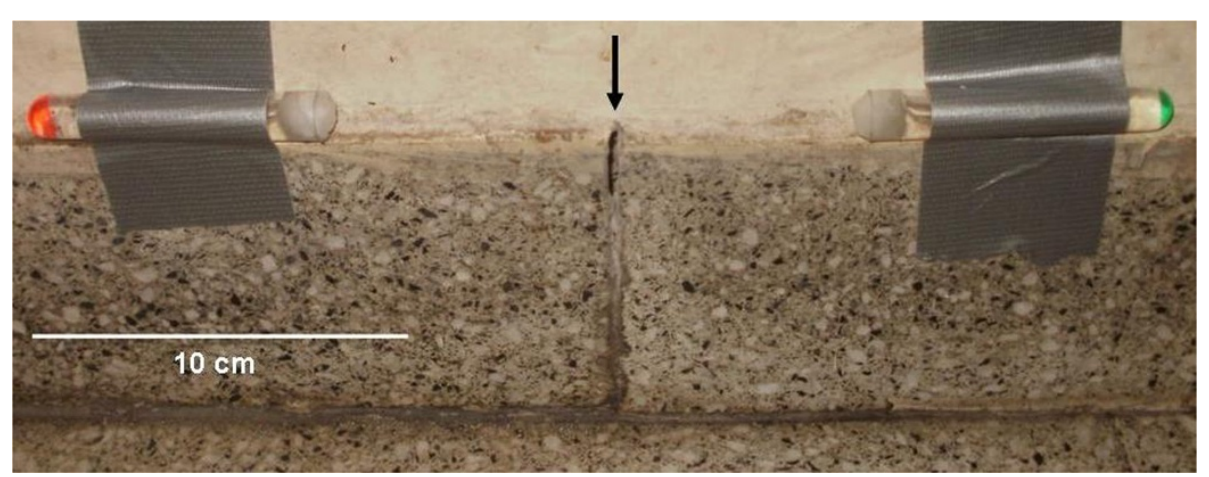

Figure 1 Bait tubes arrangement. Sets of two tubes were used: one tube with Boric Acid (BA) and the other with Borax (B). The black arrow indicates the hole that the ants use to exit. 
Table 1 List of ant morphospecies detected in the hospital considering every sample method used: pitfall trapping, baits and manual sampling either inside the buildings or outside areas

\begin{tabular}{|c|c|c|}
\hline Subfamily & Species & Observations \\
\hline Ponerinae & Gnamptogenys & Extremely rare. Individual ants on the grass, no trails were observed. \\
\hline \multirow[t]{4}{*}{ Formicinae } & Brachymyrmex patagonicus & $\begin{array}{l}\text { Abundant presence. Very small species; usually enters through tiny gaps and cracks in buildings or } \\
\text { nests therein. }\end{array}$ \\
\hline & Brachymyrmex australis & $\begin{array}{l}\text { Abundant presence. Very small species; usually enters through tiny gaps and cracks in buildings or } \\
\text { nests therein. }\end{array}$ \\
\hline & Nylanderia fulva & $\begin{array}{l}\text { One of the most abundant species. Usually enter and nest in the buildings. Long trails alongside } \\
\text { the outer walls of several pavilions. }\end{array}$ \\
\hline & $\begin{array}{l}\text { Camponotus sp (prob. } \\
\text { fuscocinctus): }\end{array}$ & Extremely rare. Arboreal, associated with green areas \\
\hline \multirow[t]{7}{*}{ Myrmicinae } & $\begin{array}{l}\text { Pheidole sp1 (cf P. rosae } \\
\text { (Wilson)) }\end{array}$ & Abundant in green areas. Not found associated to buildings. \\
\hline & $\begin{array}{l}\text { Pheidole sp2 (cf } P \text {. } \\
\text { radoszkowskii) }\end{array}$ & Abundant in green areas but rarely found inside buildings. \\
\hline & $\begin{array}{l}\text { Pheidole acutiloba } \\
\text { (Mackay) }\end{array}$ & Not abundant in green areas. It was found nesting in one pavilion. \\
\hline & Solenopsis albidula & Very small ants. They were found only on land and in the grass. \\
\hline & Acromyrmex lundi & $\begin{array}{l}\text { Black leaf-cutting ants, the biggest in the hospital. Nests are in green areas and also associated to } \\
\text { buildings. }\end{array}$ \\
\hline & Strumigenys & Very rare. Only in grass and trash. Very small ants. \\
\hline & Monomorium pharaonis & Small ants. They were only detected in one building. \\
\hline \multirow[t]{2}{*}{ Dolichoderinae } & Linepithema micans & Low abundance. In green areas. \\
\hline & Dorymyrmex brunneus & Low abundance. In green areas. \\
\hline Pseudomyrmecinae & Pseudomyrmex phyllophilus & Low abundance. Arboreal, associated with green areas. \\
\hline
\end{tabular}

probably reflects the fact that Pheidole ants are the most abundant in green areas. They could dominate a station if Nylanderia did not appear there. Nylanderia dominated a station if they found it (see Stations ST1, ST2 and ST5 in Table 2). When Nylanderia encountered the station, they recruited large numbers of individuals and Pheidole retreated as Nylanderia increased in number (Figure 3).

Nylanderia ants discovered 5 out of the 8 stations, mostly, between 40 and 50 minutes after their placement and only then, recruited workers did begin to increase in number and the gradual dropping of Pheidole started. In some stations where Nylanderia arrived after $40 \mathrm{~min}$, our recordings ended before this process was completed (see Station ST4 and ST8 in Table 2).

In conclusion, Nylanderia seems to be the behaviorally dominant ant due to their behavior of massive recruitment.

\section{Food preferences}

The different species that visited the baits have similar feeding habits, they are omnivorous and opportunistic. However, some differences were observed in the presence of ants of each genus among the four types of food baits offered (Meat, Tuna, Honey-water, Canned meat).

The three Pheidole species and N. fulva were the most abundant species at the baits and they were found in all types of food baits. However, their distribution among baits was not similar (Figures 3 and 4; Homogeneity test for all records pooled: $\mathrm{P}<0.001)$.

Considering each of these four species in particular, none of them visited the four food baits equally. Each species showed significant differences in the number of ants visiting the four food baits; that is at least one food type was either more or less visited than the others (Figure 4; Fit-Goodness Test: $\mathrm{P}<0.001$ for each species).

Although Nylanderia was found in all the foods offered, the sugary bait was the most visited and showed the fastest recruitment; tuna was preferred over the canned meat. In the case of Pheidole, the tuna bait was the least visited by the two species of Pheidole mostly represented ( $P . s p 1$ and $P . s p 2$, cf. $P$. rosae and cf. $P$. radoszkowskii, respectively). $P$. sp1 showed a preference for honey-water and canned meat, while $P . s p 2$ mainly visited canned meat over the other baits. P. acutiloba (Mackay et al. 2011) visited the honey-water significantly less compared to the other baits.

Brachymyrmex and Solenopsis were found visiting the baits in low numbers. Solenopsis albidula was found in two stations visiting at least once the Meat, Tuna and Canned meat, but with a clear preference for the meat. Brachymyrmex patagonicus was observed in only one honey-water bait. 


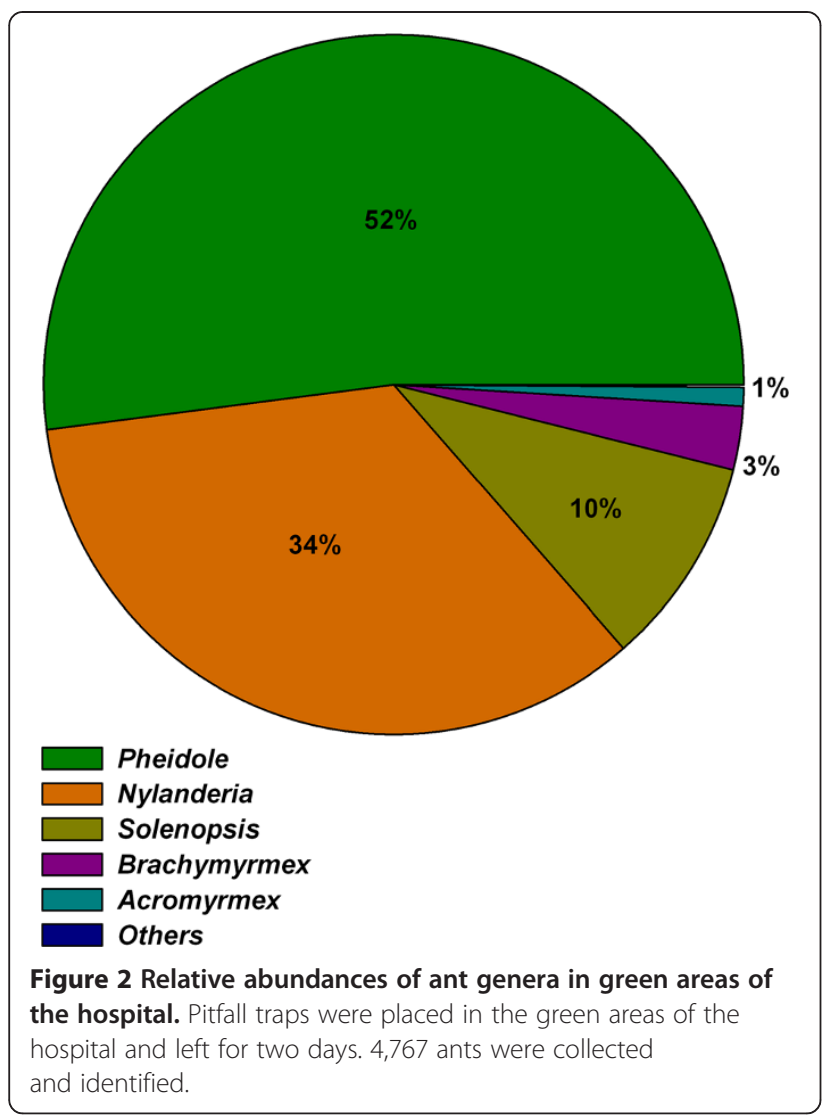

Even though we only had 8 stations, the patterns of preferences described in the previous lines were consistent. The same pattern was observed when considering all the stations together (Figure 3), only the station where each Pheidole species was dominant (Table 2:
Station ST6 for P. acutiloba; Station ST3 for P. sp1; Station $S T 7$ for P. $s p 2$ ), or even considering only the times that each species was dominant in the stations (i.e. "before" Nylanderia arrived).

\section{Control phase \\ Protocol}

Many details of the protocol to be developed indoors were determined after trying different alternatives in laboratory and from our previous research. In general terms, the protocol followed some guidelines.

As a general rule to be applied in each case, some individual ants were sampled in order to identify the species and conserved in alcohol (96\%) in flasks labeled with the capture site and date.

Regarding the collocation of the bait tubes, they were placed horizontally to ensure that the cotton plug was wet as long as possible. To promote the ants to find the mouth of the tube rapidly, a line of sugar solution was painted by means of a thin brush so that it connected each tube mouth with the ant trail. The procedure described above was followed on every occasion: two tubes close to each other were placed with two boron baits -whenever possible- in hidden places, attached horizontally with tape of the background color, etc. (see Materials and Methods).

\section{Highly infested pavilions}

The reports received from the hospital staff about ants found in rooms revealed that most of them were located on the ground floor and that several buildings along the premises were highly infested.

Table 2 Visits and behavioral dominance at the bait stations

\begin{tabular}{|c|c|c|c|c|c|}
\hline \multirow{2}{*}{$\begin{array}{l}\text { Station } \\
\text { ST } 1\end{array}$} & \multirow{2}{*}{$\begin{array}{l}\text { First genera to discover/recruit } \\
\text { to baits } \\
\text { Pheidole, Solenopsis }\end{array}$} & \multirow{2}{*}{$\begin{array}{c}\text { Time of } \boldsymbol{N f} \text { presence. } \\
>\mathbf{3} \text { workers* }\end{array}$} & \multirow{2}{*}{$\begin{array}{c}\text { Time of Nf recruit. } \\
>\mathbf{2 0} \text { workers** }^{*}\end{array}$} & \multicolumn{2}{|c|}{$\begin{array}{c}\text { Species }(\%) \text { at T7 } \\
(\text { time }=70 \mathrm{~m})\end{array}$} \\
\hline & & & & N. fulva & $(100 \%)$ \\
\hline ST 2 & Pheidole & T4 & T6 & N. fulva & (97\%) \\
\hline \multirow[t]{2}{*}{ ST 3} & Pheidole & - & - & P. sp2 & (98\%) \\
\hline & & & & N. fulva & $(43 \%) ;$ \\
\hline \multirow[t]{2}{*}{ ST 4} & Pheidole & $\mathrm{T7}$ & $\mathrm{T7}$ & B. patagonicus & $(37 \%) ;$ \\
\hline & & & & P. sp2 & (15\%) \\
\hline ST 5 & Pheidole & T5 & T6 & N. fulva & (100\%) \\
\hline ST 6 & Pheidole & - & - & P. acutiloba & (91\%) \\
\hline ST 7 & Pheidole & - & - & P. spl & (97\%) \\
\hline \multirow{2}{*}{ ST 8} & \multirow{2}{*}{ Pheidole } & \multirow{2}{*}{ T5 } & \multirow{2}{*}{-} & N. fulva & $(55 \%) ;$ \\
\hline & & & & P. sp2 & $(45 \%)$ \\
\hline
\end{tabular}

First genera to arrive at each station (STi), presence of Nylanderia fulva as the first time in which 3 (presence) and 20 (recruitment) workers were detected and behavioral dominance showed as the percentage of ant species present at the end of the recording (70 min, T7).

ST: Station; Nf: Nylanderia fulva; N.: Nylanderia; P.: Pheidole.

*; ** : First Time (from T0 to T7) at which N. fulva had at least $3\left(^{*}\right)$ or $20\left(^{* *}\right)$ workers at the station.

-: There were no workers or did not reach the indicated number. 
Following the described procedure, firstly we surrounded 3 pavilions (N, P and F) with an extensive outer baiting where children did not circulate or access. That is to say, there were walls with a lot of tubes because children had no access, and sections of walls that had no tubes at all because children were all around. Moldings or baseboards were used to support and fix the tubes as explained above. In Pavilion N, 28 tubes were placed (14 with BA and 14 with B) and for all those tubes and throughout the days recorded, the only species observed was Nylanderia fulva. In Pavilion P, 30 tubes were placed (15 BA and $15 \mathrm{~B}$ ) and the most abundant species was also N. fulva. In Pavilion F, 20 tubes were placed (10 $\mathrm{BA}$ and $10 \mathrm{~B}$ ) and the species recorded were $N$. fulva, one species of Brachymyrmex and the leaf cutting ant Acromyrmex lundi.

As the weather was turning cooler, Nylanderia ants were particularly abundant close to the heating-pipe outlets, a fact that is likely to be accentuated during the winter. In early May 2012, the temperature next to these outlets was $30^{\circ} \mathrm{C}$ (recorded on the wall next to the ant trail with a laser thermometer), while on other walls was about $20^{\circ} \mathrm{C}$.

In these pavilions Nylanderia commonly presented active trails up to ca. 20 meters long bordering the outer walls. Ants entered and exited from the building through different places, either small holes or the windows. This suggests a high connectivity between colonies with a unicolonial structure, which is common in this species.

The extensive outer baiting lasted a month and was highly effective in reducing the Nylanderia infestation indoors in all the pavilions. After this, no more N. fulva ants were detected in rooms with outer walls and in the outside for several months.

\section{Focal infested rooms}

In those focal rooms where ants were detected by the hospital staff, the entrance hole or crack inside the room through which the ants came in was searched. That was an easy task if there was high ant activity. Otherwise, if there were no ants at the moment of this evaluation, small drops of sugar-water were spread on the counters near the corners where the ants had previously been seen. Then, the first ants that appeared were followed to spot the entry. After that, the drops were cleaned.

Then, it was evaluated if the entrance hole was located in walls that limited the building to the outside or in inner walls.

In case of external walls, whenever possible, ant activity on the outside was searched, particularly in the sector that matched the indoor ant detection. If the same type of ant was on both sides of the wall, we assumed they belonged to the same colony. Following the premise that ter to attract ants outward rather than inward. 


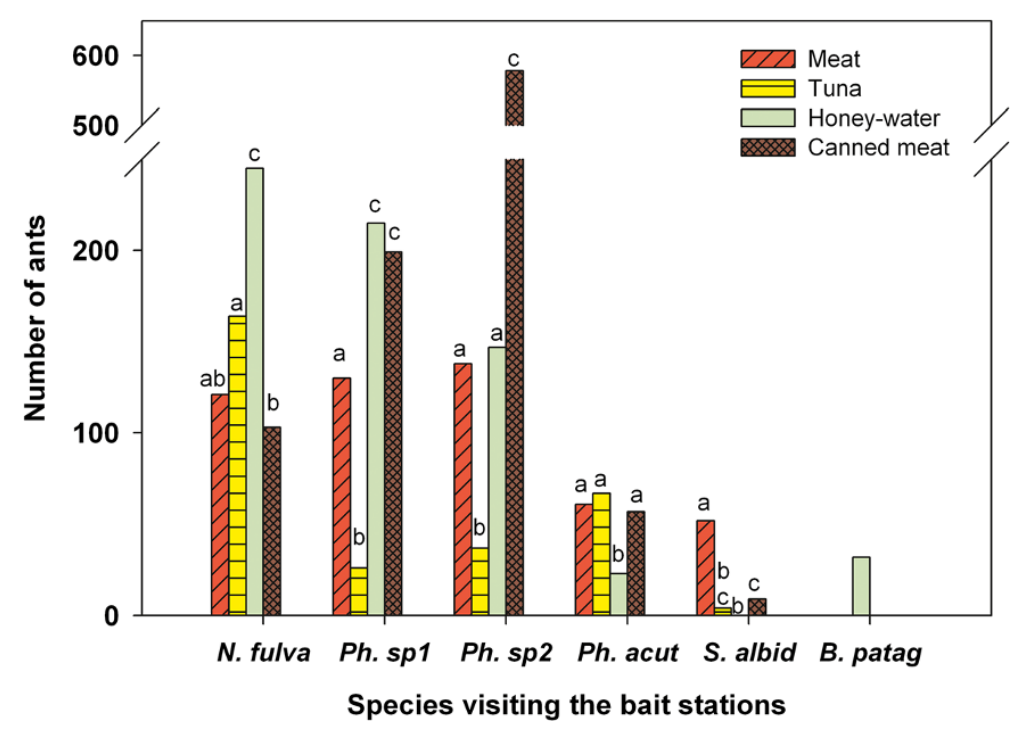

Figure 4 Preferences of each species among the four food baits offered. The 8 stations (Figure 3) and their times were pooled. For each species Goodness of fit tests were performed among food types. No letters in common among food types in each species means differences in the preference of worker visits.

it was better to attract ants outward rather than inward, baits were placed firstly on the outside.

In case of inner walls, whenever possible, ant activity on the other side of the wall was searched. If the same type of ant was also there, then we chose the less sensitive room for bait placement. Thereafter, small cracks and fissures of the more sensitive room were sealed, since the ants left for the baits in the other room. Only in cases when the other side of the wall had no ants or was inaccessible, a bait station in the affected room was set.

We were very careful in placing the baits as close as possible to the hole where the ants came out; otherwise, they could establish trails on the walls or across the countertops, which clearly had to be avoided, especially if patients were children.

After the extensive outer baiting and regarding the isolated reports of ants detected in rooms during 2012, we were warned about other 13 rooms affected by ants in different pavilions. The first 11 rooms were treated between May and July 2012 using one or two tubes per room. The tubes were refilled once or twice a week until no more ants were detected. In some cases, ant foraging on the tubes was massive, and during the refilling we could observe that about $10 \mathrm{ml}$ of $2 \%$ boron bait was consumed. For the last two rooms (12 and 13), several tubes were set and refilled only once. Table 3 summarizes data on these procedures, the species found and the results for each treatment.

The most frequent species indoors were Nylanderia fulva, Brachymyrmex patagonicus and B. australis. Out of the 13 rooms affected by ants, 6 corresponded to $N$. fulva (46\%). The activity of these ants was always particularly intense. The delay or days until non-detection (Delay in Table 3) ranged from 5 to 21 days. Four rooms were affected by Brachymyrmex (31\%): two by B. patagonicus and two by $B$. australis. In all cases the treatment was effective, ants were no longer detected between the first and second week after placing the baits.

One site (11) had very intense and constant activity of the small Pharaoh ants, Monomorium pharaonis. This laboratory consisted of 3 rooms, 2 of which were the only places in the hospital where this species was found. Two tubes (1 with BA and 1 with B) were set in each of these two rooms, and a week later no more ants were observed.

Pheidole sp1 was detected only once indoors (site 4), and this small colony showed no further activity after 5 days of treatment.

We followed up the rooms treated, both by visual assessment and by querying the staff working therein about ant detection. In all the cases mentioned above, no ants were observed in the following seven months. It is worth mentioning that in any case when ants disappeared from one place, they never appeared in a proximal other place, i.e. out of this first control experience, there was no evidence that the baiting provoked the ants to move from one place to another.

One of the two species in which the treatment was not effective was Acromyrmex lundi (leaf-cutting ants). They regularly visited the baits during the outer baiting first and then in indoor baiting. However, it is known that this species is not specialized in sugary solutions but forage for fresh plant material they need as substrate for 
Table 3 Indoor sites treated with sugar toxic baits

\begin{tabular}{|c|c|c|c|c|c|}
\hline Site & Place details & Species & $\mathrm{N}^{\circ}$ of tubes: baits applied & Result + / - & Delay \\
\hline 1 & Individual Room 4, U5 & N. fulva & 1: BA & + & 5 \\
\hline 2 & Individual Room 2, U5 & N. fulva & 1: BA & + & 13 \\
\hline 3 & Individual Room 3, U5 & N. fulva & 1: BA & + & 13 \\
\hline 4 & Office, U5 & P. spl & 2: BA, B & + & 5 \\
\hline 5 & Individual Room B, IC and office & B. patagonicus & 2: BA, B & + & 8 \\
\hline 6 & Individual Room A IC & B. australis & 2: BA, B & + & 8 \\
\hline 6 & Individual Room A IC & P. acutiloba & 2: $B A, B$ & - & $(+32)$ \\
\hline 7 & Resident physician's Bathroom, U5 & A. lundi & 2: BA, B & - & $(+30)$ \\
\hline 8 & Office, U10 & N. fulva & 2: $B A, B$ & + & 9 \\
\hline 9 & Individual Room 4, U10 & N. fulva & 1: BA & + & 21 \\
\hline 10 & Individual Room 10, U9 & N. fulva & 2: $B A, B$ & + & 15 \\
\hline 11 & Laboratory and office & M. pharaonis & 4: BA, B & + & 7 \\
\hline 12 & General room and nurse office & B. patagonicus & 10: $B A, B$ & + & 7 \\
\hline 13 & Laundry room & B. australis & 6: BA, B & + & 14 \\
\hline
\end{tabular}

Keys: N.: Nylanderia; P.: Pheidole; B.: Brachymyrmex; A.: Acromyrmex; M.: Monomorium; BA: boric acid; B: borax.

Result +: ants were no longer detected. Result -: ants were still detected. Delay: Days until shown results.

their symbiotic fungus. For this species, there are commercial granulated baits.

The other species that could not be controlled was $P$. acutiloba. This case required special work and attention because two nests were in a very sensitive area. For the first nest detected, the baits were controlled three times per week and the solutions were replaced once a week at least for a month and it still showed signs of activity. Meanwhile, we observed the ants' behavior. The activity of this colony was always very low: only one to three individuals came out of the mouth of the nest, and walked slowly without straying more than a few centimeters from it. The furthest they were seen was ca. $20 \mathrm{~cm}$ from the mouth. The tubes with the sugar baits were initially placed on the molding that formed a curve between the wall and the floor of the room. In one observation, we noticed that some ants had difficulties climbing over this curved area as they slipped down. Consequently, the tubes were placed at the ground level. Despite our efforts, this nest could not be controlled, and maintained a low level of activity, which could be seen not only by the observation of individual ants walking around, but also by construction material frequently deposited in a semicircle around the mouth of the nest.

\section{Discussion}

\section{Considerations regarding the developed protocol}

The protocol showed to be highly effective for the ants that most frequently nested in the hospital buildings (Nylanderia and Brachymyrmex). Combining two different toxicants -boric acid and borax- has proved to be particularly effective, since in all cases tested, each species visited one toxicant more than the other (data not shown).
The results were evident for patients and hospital staff. In all the sites where control measures were applied, no ants were observed in the following seven months. No further action was taken on those sites, outside or inside. Only until March and April 2013, when summer ended, some of the treated rooms did show ants again. The species were the same as those identified one year earlier; a fact that was recorded for N. fulva, Brachymyrmex and Monomorium. This suggests that the nests were not entirely eliminated, but instead the population dropped. In 2013, the same protocol was applied in the sites where ants resurged and they disappeared once more. Based on this result - and as expected- once or twice annual maintenance applications are recommended at key moments, maybe at the end of summer or early fall. In this temperate climate, where winter has temperatures than can reach zero degrees Celsius $\left({ }^{\circ} \mathrm{C}\right)$, ants tend to congregate in hot spots and heated buildings.

It is often difficult to locate ant nests, but with this protocol it is not necessary. External baiting was effective for the most abundant ant N. fulva; as placing baits outside the affected buildings resulted in a dramatic reduction in activity inside. These results coincide with previous studies involving Pharaoh ants (Haack 1991; Oi et al. 1994) and Argentine ants (Forschler and Evans 1994). It was suggested that a toxicant bait formulation could be simply scattered around the exterior periphery of a building, which would be easier to use than placing and removing bait stations (Oi et al. 1996). Even when bait station arrangement and refilling would be harder, certainly the effect of evaporation in hot weather is lower when the solution is within a tube than when scattered. On the other hand, baiting or scattering all along 
the perimeter is not applicable to sensitive areas such as pediatric hospitals because of the restrictions imposed by the children's presence. There, bait stations required to be localized in place where children had no access, along the perimeter. Nonetheless, it proved to be effective.

\section{Considerations regarding the hospital}

In relation to the situation of the hospital, there are several issues that hinder ant control within buildings.

The buildings had many small holes that allowed ants enter the walls where they could nest and then exit in the inside. In this sense it was important for us to seal the smaller holes by using silicone and also to work together with the maintenance staff in order to repair deteriorated walls in some sensitive rooms.

The patients' visitors' habits seem to be difficult to control. On several occasions we detected ants collecting food in garbage thrown into the bathroom waste basket. Even though visitors are aware that this induces insects to enter the rooms, as indicated by nurses, they state that it is easier for them to do so. It is difficult to change these habits, thus, it should be important to implement some measures in order to increase the visitors' awareness of the problem or even evaluate an alternative measure so that they can get rid of food wastes in the rooms in a safer way to prevent insect attraction.

\section{The ants}

In this survey on the ant species present in the hospital, we found 7 different ant species indoor and a total of 15 species considering both indoor and green areas. Several studies have demonstrated a great variability of ant assemblage richness and species composition associated with human structures in Brazil, even in hospitals (Fowler et al. 1993; Bueno and Fowler 1994). This is unlike the findings of studies reported from Europe and North America, which have few associated species. It is natural to expect a small number of species in hospitals of temperate climates (Fowler et al. 1993). However, we have found in a hospital of Buenos Aires a similar number of species to several hospitals of Brazil, despite our temperate climate.

It is possible that for some species, the observed activity was low because the ants had different time patterns, being more active at night, dusk or dawn rather than in the middle of the day. However, the pitfall traps could collect and show such an activity as they were left for 48 h. Besides, hospital staff could detect and report ant activity indoors at any time of the day.

Nylanderia fulva resulted to be the main species in association with the buildings. In green areas throughout the hospital we saw the coexistence of $N$. fulva with Pheidole, Brachymyrmex and Solenopsis. This coexistence had previously been observed in other urban environments (McDonald 2012). Nylanderia accepted all food baits, but the most visited was the sugary bait. This is in accordance with other studies, where sugar based baits were preferred over protein in the laboratory (Cook et al. 2011) and in the field (Lynch et al. 1980). Another study found that N. fulva was apparently not attracted to oil based baits (Drees et al. 2010); however, tuna in oil was the second most accepted bait in this study.

Nylanderia was typically found in trash cans and restroom drains, but it was also observed in the beds of patients. Oral reports from nurses indicated that if dextrose serum leaked during routine handling, ants would subsequently appear.

A recent study on $N$. fulva (McDonald 2012) mentioned that it is not attracted to most commercial ant baits but one granular product. Some treatments involving insecticides applied to surfaces provided temporary buffer zones around structures, only partially controlling $N$. fulva. Field assessments of the only commercial bait that $N$. fulva found attractive was not effective for control: reduction in the number of ants was low, and after the third or fourth week numbers returned to levels prior to treatment. Although other authors (ZennerPolania 1990) concluded that effective control of $N$. fulva could not be accomplished through a single control method, we found that our bait and application method were sufficient to control localized populations for up to 7 months. We do not disregard the fact that in temperate climates, harsh winters can work in favor of extending control effectiveness.

Brachymyrmex was observed in kitchens, offices, laundry rooms; also in neonatal units. These ants showed an intense activity and quick visits to the baits once placed. Brachymyrmex patagonicus was described as an invader ant in the USA, where it nests in natural and disturbed areas, and it is also found in very high numbers in hospitals and other buildings (MacGown et al. 2007). Its diet consists largely of honeydew of different insects, so it is expected to readily recruit to sweet baits. In fact, this was observed in the food bait stations where they were detected only in the sugary bait and also in the effectiveness of the toxic sugar bait used for control. Brachymyrmex ants have been found as the most frequent species in some hospitals in Porto Alegre, Brazil (Garcia et al. 2011).

Monomorium pharaonis, the Pharaoh ants, were detected only indoors, which coincides with observations for this species which nests primarily indoors in temperate regions (Ebeling 1978). The sugar toxic baits were well accepted and promptly effective. These ants compensate for what they are lacking nutritionally by foraging on either carbohydrates or proteins (Edwards and Abraham 1990). M. pharaonis was dominant in several hospitals in Brazil (Fowler et al. 1993; Lise et al. 2006), 
as well as in temperate climates such as in England (Edwards and Baker 1981). Nevertheless, we only found this species in one laboratory of our hospital in Buenos Aires.

Generally speaking, Pheidole is a very diverse genus composed mainly of omnivorous ants. Some groups of species were characterized as specialized, either strict granivores or carnivores (Kusnezov 1951). Carnivores can forage on dead or alive insects but also feed on sweet liquids such as honeydew or extrafloral nectars (Blom and Clark 1980). However, P. grallipes that was thought to be exclusively entomophagus, resulted to have a more diversified diet (Clark et al. 1986), and two other Pheidole from Argentina also revealed that they were less specialized than expected (Pirk et al. 2009). In a hospital in Brazil, a Pheidole ant visited equally sugar and protein baits (Pesquero et al. 2008), which coincides with two species of Pheidole found in our study which collected protein and sugar bait as well.

$P$. acutiloba preferred the sugary baits less than the protein baits. Considering that sugar was not a main resource for this ant, in the indoor control situation, after some weeks of no response toward the boron baits, we tried a mixed amino acid-sucrose solution; however, no signs of ants drinking on it were observed either. Therefore, it is possible that this species avoids liquid baits. A study on a laboratory colony of a Pheidole species offering simultaneously 4 different vehicles for $30 \%$ sucrose bait, suggested a preference for dry vehicles (Lee 2008).

As mentioned above, $P$. acutiloba proved to be the only species among those observed on the food bait stations that visited significantly less the sugary bait than the other foods. This result could explain the low effectiveness of the toxic bait used with this particular species, confirming the need to consider the food preferences of the target species for bait formulations. Eichler (1990) suggested the use of "pre-baits" for M. pharaonis in order to determine their preferences; this recommendation is valid for many species, especially for those whose feeding habits are unknown.

In summary, more and more studies conclude that it is necessary to consider the behavior and nutritional preferences of the target species, and also the toxic to be used for the baits when designing control programs (Lee 2008; Sola et al. 2013). For the species where sugary baits did not work, a bait-preference test could indicate the most appropriate bait to use in that particular case. In this sense, we are still working on increasing the acceptance of sugar toxic baits in situations where they are not well accepted.

As mentioned previously, the fact that the species and locations were the same from one year to the next shows that total eradication of the pest ants was not possible in this instance. However, we were able to control the populations of problematic ants eliminating their detection from inside buildings. Based on this, we suggest consistent and regular population monitoring and the use of an integrated management to achieve proper levels of pest control.

\section{Competing interests}

The authors declare that they have no competing interests.

\section{Authors' contribution}

RJ was project director, coordinated field sampling, made all the control procedures indoors and was main writer of the manuscript. FJS co-coordinated field sampling, was responsible for ant species identification and contributed to drafting of manuscript. NM was a field assistant and contributed to sample processing in the lab. MADR was responsible for bait monitoring, data centralization and analysis, and contributed to manuscript. AG was responsible for bait monitoring, sample processing, and contributed to manuscript. All authors read and approved the final manuscript.

\section{Acknowledgements}

We would like to thank the Hospital Authorities, medical and general staff for their support and kindness. Special thanks to Isabel Ortega Insaurralde, Tomás Righetti, Pablo Jusim for their collaboration in outdoor tasks at the hospital.

This study was supported by the National Agency for Scientific and Technological Promotion (PICT 2007-01319) and the National Council for Scientific and Technological Research of Argentina.

All necessary permits were obtained for the described study, which complied with all relevant regulations. The species we worked on are not endangered or protected. We had the permissions required for these activities in the hospital from the corresponding authorities.

Received: 4 March 2014 Accepted: 24 April 2014

Published: 6 May 2014

\section{References}

Alexander FE, Patheal SL, Biondi A, Brandalise S, Cabrera ME, Chan LC, Chen Z, Cimino G, Cordoba JC, Gu LJ, Hussein H, Ishii E, Kamel AM, Labra S, Magalhães IQ, Mizutani S, Petridou E, Pombo de Oliveira M, Yuen P, Wiemels JL, Greaves MF (2001) Transplacental chemical exposure and risk of infant leukemia with MLL gene fusion. Cancer Res 61:2542-2546

Andersen AN (1997) Functional groups and patterns of organization in North American ant communities: a comparison with Australia. J Biogeogr 24:433-460

Bailey HD, Armstrong BK, de Klerk NH, Fritschi L, Attia J, Scott RJ, Smibert E, Milnel $E$ (2011) Exposure to professional pest control treatments and the risk of childhood acute lymphoblastic leukemia. Int J Cancer 129:1678-1688

Baker TC, Van Vorhis Key SE, Gaston LK (1985) Bait-preference tests for the Argentine ant (Hymenoptera: Formicidae). J Econ Entomol 78:1083-1088

Beatson SH (1972) Pharaoh's ants as pathogen vectors in hospitals. Lancet 1:425-427

Blom PE, Clark WH (1980) Observations of ants (Hymenoptera: Formicidae) visiting extrafloral nectaries of the barrel cactus Ferrocactus gracilis (Cactaceae) in Baja California, Mexico. Southwest Nat 25:181-196

Buczkowski G, Scharf ME, Ratliff CR, Bennett GW (2005) Efficacy of simulated barrier treatments against laboratory colonies of Pharaoh ant. J Econ Entomol 98:485-492

Bueno OC, Campos-Farinha AEC (1999) As formigas domésticas. In: Mariconi FAM (ed) Insetos e outros invasores de residências. Fundação de Estudos Agrários Luiz de Queiroz, Piracicaba, pp 135-180

Bueno OC, Fowler HG (1994) Exotic ants and native ant fauna of Brazilian hospitals. In: Williams DF (ed) Exotic ants - Biology, impact and control of introduced species. Westview Press, Boulder, pp 191-198

Cassill DL, Tschinkel WR (1999) Regulation of diet in the fire ant, Solenopsis invicta. J Insect Behav 12:307-328

Clark WH, Blom PE, Lownam AM (1986) Contents of a nest of the desert ant, Pheidole grallipes wheeler, in Baja California, Mexico. Pan-Pac Entomol 62:99-102

Cook S, Wynalda R, Gold R, Behmer S (2011) Macronutrient regulation in the Rasberry crazy ant (Nylanderia sp. nr. pubens). Insect Soc 59:1-8

Dornhaus A, Collins EJ, Dechaume-Moncharmont FX, Houston Al, Franks NR, McNamara JM (2006) Paying for information: partial loads in central place foragers. Behav Ecol Sociobiol 61:151-161 
Drees BM, McDonald DL, Calixto A, Nester P, Bowen C, Rasberry T, Gold R (2010) Evaluation of bait attractiveness for the Rasberry crazy ant. 2010 IPM Handbook, pp 93-95

Ebeling W (1978) Urban Entomology. Division of Agricultural Sciences University of California, Berkeley

Edwards JP, Abraham L (1990) Changes in food selection by workers of the Pharaoh's ant, Monomorium pharaonis. Med Vet Entomol 4:205-211

Edwards JP, Baker LF (1981) Distribution and importance of the Pharaoh's ant Monomorium pharaonis (L.) in National Health Service hospitals in England. J Hosp Infect 2:249-254

Eichler W (1990) Health aspects and control of Monomorium pharaonis. In: Vander Meer RK, Jaffe K, Cedeno A (ed) Applied Myrmecology: A World Perspective. Westview Press, Boulder, pp 671-675

Falibene A, Josens R (2008) Nectar intake rate is modulated by changes in sucking pump activity according to colony starvation in carpenter ants. J Comp Physiol A 194:491-500

Falibene A, Figueiredo Gontijo A, Josens R (2009) Sucking pump activity in feeding behaviour regulation in carpenter ants. J Insect Physiol 55:518-524

Fellers JH (1987) Interference and exploitation in a guild of woodland ants. Ecology 69:1466-1478

Fernández F (2003) Introducción a Las Hormigas de la Región Neotropical. Instituto de Investigación de Recursos biológicos Alexander von Humboldt, Bogotá

Forschler BT, Evans GM (1994) Perimeter treatment strategy using containerized baits to manage Argentine ants, Linepithema humile (Mayr) (Hymenoptera: Formicidae). J Entomol Sci 29:264-267

Fowler HG, Bueno OC, Sadastsune T, Montelli A (1993) Ants as potential vectors of pathogens in hospitals in the state of São Paulo, Brazil. Int J Trop Insect Sci 14:367-370

Garcia FRM, Ahlert CC, de Freitas BR, Trautmann MM, Tancredo SP, Lutinski JA (2011) Ants (Hymenoptera: Formicidae) in five hospitals of Porto Alegre, Rio Grande do Sul State, Brazil. Acta Scientiarum Health Sci 33:203-209

Haack KD (1991) Elimination of Pharaoh ants, an analysis of field trials with ProControl and Maxforce ant baits. Pest Control Technol 19:32-33

Hansen LD, Klotz JH (2005) Carpenter Ants of the United States and Canada. Cornell Univ. Press, Ithaca, NY

Hedges SA (2010) Field Guide for the Management of Structure - Infesting Ants. GIE Inc Publishers, Richfield

Herin F, Boutet-Robinet E, Levant A, Dulaurent S, Manika M, Galatry-Bouju F, Caron P, Soulat JM (2011) Thyroid function tests in persons with occupational exposure to fipronil. Thyroid 21:701-706

Hooper-Bui LM, Rust MK (2001) An oral bioassay for the toxicity of hydramethylnon to individual workers and queens of Argentine ants, Linepithema humile. Pest Manag Sci 57:1011-1016

Howard DF, Tschinkel WR (1980) The effect of colony size and starvation on food flow in the fire ant, Solenopsis invicta (Hymenoptera: Formicidae). Behav Ecol Sociobiol 7:293-300

Infante-Rivard C, Labuda D, Krajinovic M, Sinnett D (1999) Risk of childhood leukemia associated with exposure to pesticides and with gene polymorphisms. Epidemiology 10:481-489

Josens R, Roces F (2000) Foraging in the ant Camponotus mus: nectar intake rate and crop filling depend on colony starvation. J Insect Physiol 46:1103-1110

Josens R, Farina WM, Roces F (1998) Nectar feeding by the ant Camponotus mus: intake rate and crop filling as a function of sucrose concentration. J Insect Physiol 44:579-585

Kapoor U, Srivastava MK, Srivastava LP (2011) Toxicological impact of technical imidacloprid on ovarian morphology, hormones and antioxidant enzymes in female rats. Food Chem Toxicol 49:3086-3089

Klotz JH (2004) Liquid bait delivery systems for controlling Argentine ants in citrus groves (Hymenoptera: Formicidae). Sociobiol 43:419-427

Klotz JH, Greenberg L, Amrhein C, Rust M (2000) Toxicity and repellency of borate-sucrose water baits to Argentine ants (Hymenoptera: Formicidae). J Econ Entomol 93:1256-1258

Klotz JH, Hansen L, Pospischil R, Rust M (2008) Urban Ants of North America and Europe. Identification, Biology and Management. Cornell University Press, Ithaca

Klotz JH, Hansen L, Field H, Rust M, Oi D, Kupfer K (2010) Urban Pest Management of Ants in California. Division of Agricultural and Natural Resources University of California, Richmond

Kusnezov N (1951) El Género "Pheidole" en la Argentina (Hymenoptera Formicidae). Acta Zool Lilloana 12:5-88
Kusnezov N (1978) Hormigas argentinas - Clave para su identificación. Fundación Miguel Lillo. Miscelánea 61, Tucumán

Lee CY (2008) Sucrose bait base preference of selected urban pest ants (Hymenoptera: Formicidae). In: Robinson WH, Bajomi D (ed) Proceedings of the Sixth International Conference on Urban Pests. OOK-Press Kft, Veszprém, pp 59-63

Leiss JK, Savitz DA (1995) Home pesticide use and childhood cancer: a casecontrol study. Am J Public Health 85:249-252

Lise F, Garcia FRM, Lutinski JA (2006) Association of ants (Hymenoptera: Formicidae) with bacteria in hospitals in the State of Santa Catarina. Rev Soc Bras Med Trop 39:523-526

Lynch JF, Balinsky EC, Vail SG (1980) Foraging patterns in three sympatric forest ant species, Prenolepis imparis, Paratrechina melanderi and Aphaenogaster rudis (Hymenoptera: Formicidae). Ecol Entomol 5:353-371

Ma X, Buffler PA, Gunier RB, Dahl G, Smith MT, Reinier K, Reynolds P (2002) Critical windows of exposure to household pesticides and risk of childhood leukemia. Environ Health Perspect 110:955-960

MacGown JA, Hill JG, Deyrup MA (2007) Brachymyrmex patagonicus (Hymenoptera: Formicidae), an emerging pest species in the southeastern United States. Fla Entomol 90:457-464

MacKay WP, Mackay E (2002) The ants of New Mexico (Hymentoptera: Formicidae). Edwin Mellen Press, Lewiston

Mackay WP, Sola FJ, Josens R (2011) A new shield-faced ant of the genus Pheidole (Hymenoptera: Formicidae: aberrans Group) from Argentina. Trans Am Entomol Soc 137:297-305

Mailleux AC, Detrain C, Deneubourg $J$ (2006) Starvation drives a triggering communication. J Exp Biol 209:4224-4229

Mallis A (1969) Handbook of Pest Control. MacNair-Dorland Co., New York

Markin GP (1970) Foraging Behavior of the Argentine Ant in a California Citrus Grove. J Econ Entomol 63(3):740-744

McDonald DL (2012) Investigation of an invasive ant species: Nylanderia fulva. Colony extraction, management, diet preference, fecundity, and mechanical vector potential. Doctoral dissertation. Texas A \& M University.

Medan $V$, Josens R (2005) Nectar foraging behaviour is affected by ant body size in Camponotus mus. J Insect Physiol 51:853-860

Menegaux F, Baruchel A, Bertrand Y, Lescoeur B, Leverger G, Nelken B, Sommelet D, Hémon D, Clavel J (2006) Household exposure to pesticides and risk of childhood acute leukaemia. Occup Environ Med 63:131-134

Moreira DDO, Morais V, Vieira-da-Motta O, Campos-Farinha AEC, Tonhasca JA (2005) Ants as carriers of antibiotic-resistant bacteria in hospitals. Neotrop Entomol 34:999-1006

Morrison LW, Kawazoe EA, Guerra R, Gilbert LE (2000) Ecological Interactions of Pseudacteon parasitoids and Solenopsis ant hosts: environmental correlates of activity and effects on competitive hierarchies. Ecol Entomol 25:433-444

Newell W, Barber TC (1913) The Argentine ant. US Dept Agric Bureau of Entomology Bulletin, p 122

O'Brien KS, Hooper-Bui LM (2005) Hunger in red imported fire ants and their behavioral response to two liquid bait products. J Econ Entomol 98:2153-2159

Oi DH (2008) Pharaoh ants and fire ants. In: Bonnefoy X, Kampen H, Sweeney K (ed) Public Health Significance of Urban Pests. WHO, Copenhagen, pp 175-208

Oi DH, Vail KM, Williams DF, Bieman DN (1994) Indoor and outdoor foraging locations of Pharaoh ants (Hymenoptera: Formicidae) and control strategies using bait stations. Fla Entomol 77:85-91

Oi DH, Vail KM, Williams DF (1996) Field evaluation of perimeter treatments for Pharaoh ant (Hymenoptera: Formicidae) control. Fla Entomol 79:252-263

Olaya-Masmela LA, Chacón de Ulloa P, Payán A (2005) Hormigas (Hymenoptera: Formicidae) en centros hospitalarios del Valle del Cauca como vectores de patógenos nosocomiales. Rev Colomb Entomol 31:183-187

Owens K (2003) Healthy Hospitals: Controlling Pest Without Harmful Pesticides. Beyond Pesticides, Washington

Pampiglione G, Velo E (2010) Pest control in Albania: an example of collaboration in technical and scientific development in public health. Vet Ital 46:37-43

Pesquero MA, Elias-Filho J, Carneiro LC, Feitosa SB, Oliveira MA, Quintana RC (2008) Formigas em ambiente hospitalar e seu potencial como transmissoras de bactérias. Neotrop Entomol 37:472-477

Pirk Gl, Lopez de Casenave J, Pol R, Marone L, Milesi F (2009) Influence of temporal fluctuations in seed abundance on the diet of harvester ants (Pogonomyrmex spp.) in the central Monte desert, Argentina. Austral Ecol 34:908-919 
Pombo-de-Oliveira MS, Koifman S (2006) Infant acute leukemia and maternal exposures during pregnancy. Cancer Epidemiol Biomarkers Prev 15:2336-2341

Rudant J, Menegaux F, Leverger G, Baruchel A, Nelken B, Bertrand Y, Patte C, Pacquement H, Vérité C, Robert A, Michel G, Margueritte G, Gandemer V, Hémon D, Clavel J (2007) Household exposure to pesticides and risk of childhood hematopoietic malignancies: the ESCALE study (SFCE). Environ Health Perspect 115:1787-1793

Santos PF, Fonseca AR, Sanchez NM (2009) Formigas (Hymenoptera: Formicidae) como vetores de bactérias em dois hospitais do município de Divinópolis, Estado de Minas Gerais. Rev Soc Bras Med Trop 42:565-569

Savolainen R, Vepsäläinen K (1988) A competition hierarchy among boreal ants: impact on resource partitioning and community structure. Oikos 51:135-155

Shannon WM, Borron SW, Burns MJ (2007) Haddad and Winchester's Clinical Management of Poisoning and drug overdose. WB Saunders Company, Philadelphia

Silverman J, Roulston TH (2001) Acceptance and intake of gel and liquid sucrose compositions by the Argentine ant (Hymenoptera: Formicidae). J Econ Entomol 94:511-515

Sola F, Falibene A, Josens R (2013) Asymmetrical behavioral response toward two boron toxicants depends on the ant species (Hymenoptera: Formicidae). J Econ Entomol 106:929-938

Thompson JR, Gerald PF, Willoughby ML, Armstrong BK (2001) Maternal folate supplementation in pregnancy and protection against acute lymphoblastic leukaemia in childhood: a case-control study. Lancet 358:1935-1940

Wilson EO (2003) Pheidole in the New World: a dominant, hyperdiverse ant genus, vol 1. Harvard University Press, Cambridge, USA

Winans B, Humble MC, Lawrence BP (2011) Environmental toxicants and the developing immune system: a missing link in the global battle against infectious disease? Reprod Toxicol 31:327-336

Zenner-Polania I (1990) Biological aspects of the "Hormiga Loca" Paratrechina (Nylanderia) fulva (Mayr), in Colombia. In: Vander Meer RK, Jaffe K, Cedeno A (ed) Applied Myrmecology: A World Perspective. Westview Press, Boulder, pp 290-297

doi:10.1186/2193-1801-3-229

Cite this article as: Josens et al:: Knowing the enemy: ant behavior and control in a pediatric hospital of Buenos Aires. SpringerPlus 2014 3:229.

\section{Submit your manuscript to a SpringerOpen ${ }^{\odot}$ journal and benefit from:}

- Convenient online submission

- Rigorous peer review

- Immediate publication on acceptance

- Open access: articles freely available online

- High visibility within the field

- Retaining the copyright to your article

Submit your next manuscript at $\boldsymbol{~ s p r i n g e r o p e n . c o m ~}$ 